\title{
Heavy metals levels in fish from aquaculture farms and risk assessment in Lhasa, Tibetan Autonomous Region of China
}

\author{
Dongsheng Jiang • Zhenzhen Hu • Feng Liu • \\ Rongfei Zhang $\cdot$ Bu Duo $\cdot$ Jianjie Fu $\cdot$ \\ Yibin Cui • Mei Li
}

Accepted: 7 March 2014/Published online: 27 March 2014

(C) Springer Science+Business Media New York 2014

\begin{abstract}
Fish is consumed as a common food by humans due to its nutritional and therapeutic benefits. However, they can accumulate toxic chemicals (such as heavy metals, persistent organic pollutants) from water and food chain. Very few studies have been investigated on heavy metal contents in fish from Tibetan Autonomous Region of China. In order to study heavy metals levels in fish from aquaculture farms and evaluate the risk that human consume fish in this area, we collected four types of aquaculture fish species ( 6 big-head carps, 5 grass carps, 5 carps and 5 tilapias) from fisheries around Lhasa city in this study. 9 heavy metals $(\mathrm{Cr}, \mathrm{As}, \mathrm{Cd}, \mathrm{Pb}, \mathrm{Cu}, \mathrm{Ba}, \mathrm{Co}, \mathrm{Mn}$ and $\mathrm{V})$ in different tissues of fish were determined by an inductively coupled plasma mass spectrometer. $\mathrm{Cr}, \mathrm{Ba}, \mathrm{Co}$, $\mathrm{Mn}$ and $\mathrm{V}$ could easily accumulate in the gill, and $\mathrm{Cu}$ was detected in the hearts of all the fishes. Toxic metal (As, $\mathrm{Cd}$ and $\mathrm{Pb}$ ) contents were higher in the liver than those in other tissues, heavy metal levels were the lowest in the muscle among all tissues. Most of heavy metal concentrations in the tilapia tissues were higher than those in other fish tissues, especially arsenic. Arsenic content in the tilapia samples was $\sim 2-4$ times higher than the maximum levels
\end{abstract}

D. Jiang $\cdot$ Z. Hu $\cdot$ F. Liu $\cdot$ R. Zhang $\cdot$ Y. Cui $(\bowtie) \cdot$ M. Li State Key Laboratory of Pollution Control \& Resource Reuse, School of the Environment, Nanjing University, Xianlin Campus, Nanjing 210023, People's Republic of China e-mail: cuiyb@nju.edu.cn

B. Duo

Faculty of Science, Tibet University, Lhasa 850000, People's Republic of China

J. Fu

Research Center for Eco-Environmental Sciences, Chinese Academy of Sciences, Beijing 100085, People's Republic of China
(MLs) of contaminants in the national standard, and other metals were all lower than the MLs. Compared the estimated daily intake of heavy metals through fish consumption with tolerable daily intakes recommended by $\mathrm{FAO}$, the metals daily intake of $\mathrm{As}, \mathrm{Cd}$ and $\mathrm{Pb}$ from fish consumption might not pose serious health risk to the local inhabitants. It is therefore necessary to determine the dose level for human, which is considered to be taken daily over a lifetime without adverse effects.

Keywords Aquaculture fish farm · Heavy metal . Estimated daily intakes (EDI) - Tolerable daily intakes (TDI) · Lhasa

\section{Introduction}

Fish consumption is recommended due to its nutritional and therapeutic benefits. The benefits of fish are mainly due to the content of high quality protein, high content of two kinds of omega 3 poly unsaturated fatty acids: eicosapentaenoic acid (EPA) and docosahexaenoic acid (DHA) and other nutrients (Castro-Gonzalez 2002; Clarkson 2002; Dominogo et al. 2007). The American Heart Association recommends to eat fish at least two times per week in order to reach the daily intake of omega 3 fatty acids for avoiding heart disease on certain extent (Kris-Etherton et al. 2002). However, the rapid development of economy has resulted in increasing pollution. Heavy metals (such as mercury, cadmium, copper, lead, etc.) are ubiquitous and persistent contaminants in both freshwater and marine environment (Devlin 2006; Ozmen et al. 2006; Macken et al. 2009) and these pollutants would finally human by consuming the contaminated fish (Ramirez-Perez et al. 2004; Sawasdee and Kohler 2010). Specially, cadmium is toxic to the 
kidney and has a long biological half-life in human, it is possible that high concentrations of cadmium can inhibit ChE activity through binding with sulfhydryl groups in or near active sites of enzymes (Silva and Pathiratne 2008). Inorganic arsenic is a human carcinogen, which is the most toxic speciation of arsenic. Lead has shown to be associated with damnification of central nervous system, leading to decrements of intelligence quotients in children (Baars et al. 2001). Also, for these reasons, they have caused great environmental concern.

When heavy metals are released into rivers, they could accumulate to higher degree in gill and liver tissues of fish (Ozmen et al. 2006), and can be biomagnified through food chain, resulting in sub-lethal effects or even death in local fish populations (Megeer et al. 2000; Jones et al. 2001; Almeida et al. 2002; Xu et al. 2004). On one hand, fish could accumulate heavy metals from aquatic environment, on the other hand, they also could uptake heavy metals through feed. And heavy metals could transferred to higher trophic levels and even enter into human body (Heier et al. 2009). Eventually, dietary intake of these biomagnified species poses risk to human health as fish occupied a significant part of human diet (Türkmen et al. 2005).

The economy develops quickly in Tibet, especially the vicinity of Lhasa in recent years. Lhasa covers an area of close to 30,000 square $\mathrm{km}$, which has a downtown of 544 square $\mathrm{km}$ and a population of 400,000, 140,000 of its people live in the downtown area. The boom of mining industry and agriculture has resulted in heavy metals pollution in Lhasa, the concentrations of $\mathrm{Cu}, \mathrm{Pb}, \mathrm{Zn}, \mathrm{Mn}, \mathrm{Fe}$ and $\mathrm{Al}$ in the surface water and streambed at the upper/ middle part of Gyama valley, a metal mine of Lhasa, pose a considerably high risk to the local environment (Huang et al. 2010). The consumption of aquatic products is also very common in this region. Because of the high altitude, the fish consumed mainly from local aquaculture, thus the quality of aquatic products will be directly related to the health of consumers.

In this study, we collected fish samples from two aquaculture production sites around Lhasa in Tibetan Autonomous Region, China. First, the extent of heavy metal contamination and the relationship among muscle, liver, gill and heart of fishes were investigated. Second, As, $\mathrm{Cd}$ and $\mathrm{Pb}$ were chosen for risk assessment because of their high toxicities or comparatively high levels in fish samples. Assessments of the daily dietary exposures of these metals to the local population through consumption of fish were calculated. By comparing with the provisional tolerable weekly intakes (PTWI) for heavy metals suggested by FAO/WHO (WHO 1993), the potential health risk to local inhabitants was then evaluated.

\section{Materials and methods}

Sites description and samplings

Lhasa $\left(91^{\circ} 06^{\prime} \mathrm{E}, 29^{\circ} 36^{\prime} \mathrm{N}\right)$ is the political, economic and cultural center of the Tibet, which has an about 1/4 population of the Tibetan Autonomous Region. It is located at the bottom of a small basin surrounded by mountains, which has an altitude of $3,650 \mathrm{~m}$. Further, Lhasa is an important tourist area in Tibet Autonomous Region and fish is one of the major food for the local people and tourists.

Fish samples were collected from two different aquaculture fisheries located in Lhunzhun County and Gonggar County, respectively (Fig. 1). Lhunzhun fishery $\left(91^{\circ} 05^{\prime} \mathrm{E}\right.$, $29^{\circ} 17^{\prime} \mathrm{N}$ ) is about $65 \mathrm{~km}$ from Lhasa City with an area of 150,000 square meters, which is next to the county government. The area of Gonggar fishery $\left(91^{\circ} 15^{\prime} \mathrm{E}, 29^{\circ} 52^{\prime} \mathrm{N}\right)$ is about 270,000 square meters, which is about $120 \mathrm{~km}$ from Lhasa City. These two aquacultural fish farms are the largest fisheries around Lhasa, their fish products are mainly sold in Lhasa market.

Fish and related water samples were collected in July 2010. Six big-head carps were collected from Lhunzhun fishery, five carps, five grass carps and five tilapias were collected from Gonggar fishery separately. Fish sample was put in zip-lock polyethylene bags and then transferred to lab within $3 \mathrm{~h}$. The gill, muscle, liver and heart were separated in lab immediately, and stored at $-20^{\circ} \mathrm{C}$ until processing for metal analysis.

Sample analysis

All freeze-dried muscle, gill, heart, liver samples were crushed, sieved, grinded, and mixed to homogenize the samples, respectively. Approximately $0.2 \mathrm{~g}$ fish sample was weighted and put into a Teflon digestion vessel. $2 \mathrm{~mL}$ concentrated nitric acid (69\%, analytical grade, SigmaAldrich) was added to each container and the samples were predigested at $60^{\circ} \mathrm{C}$ about $4 \mathrm{~h}$. When the sample was cooled down to room temperature, $1 \mathrm{~mL}$ of $30 \%$ hydrogen peroxide (granted regent, Beijing Chemical Company) was added and the sample was digested using a microwave digestion unit (CEM Mars-X500, USA) under the following conditions: the temperature was firstly raised to $160{ }^{\circ} \mathrm{C}$ in $10 \mathrm{~min}$ and kept for $30 \mathrm{~min}$, then the oven temperature ramp from 160 to $180{ }^{\circ} \mathrm{C}$ in $10 \mathrm{~min}$ and hold for $30 \mathrm{~min}$. After cooling down, the digest was then diluted to $40 \mathrm{~mL}$ with Milli-Q water for analysis. $\mathrm{Cr}, \mathrm{As}, \mathrm{Cd}, \mathrm{Pb}, \mathrm{Cu}, \mathrm{Ba}, \mathrm{Co}$, $\mathrm{Mn}$ and $\mathrm{V}$ were analyzed by inductively coupled plasma mass spectrometer (ICP-MS, Agilent 7500ce, USA). 
Fig. 1 Sampling locations in Lhasa, China

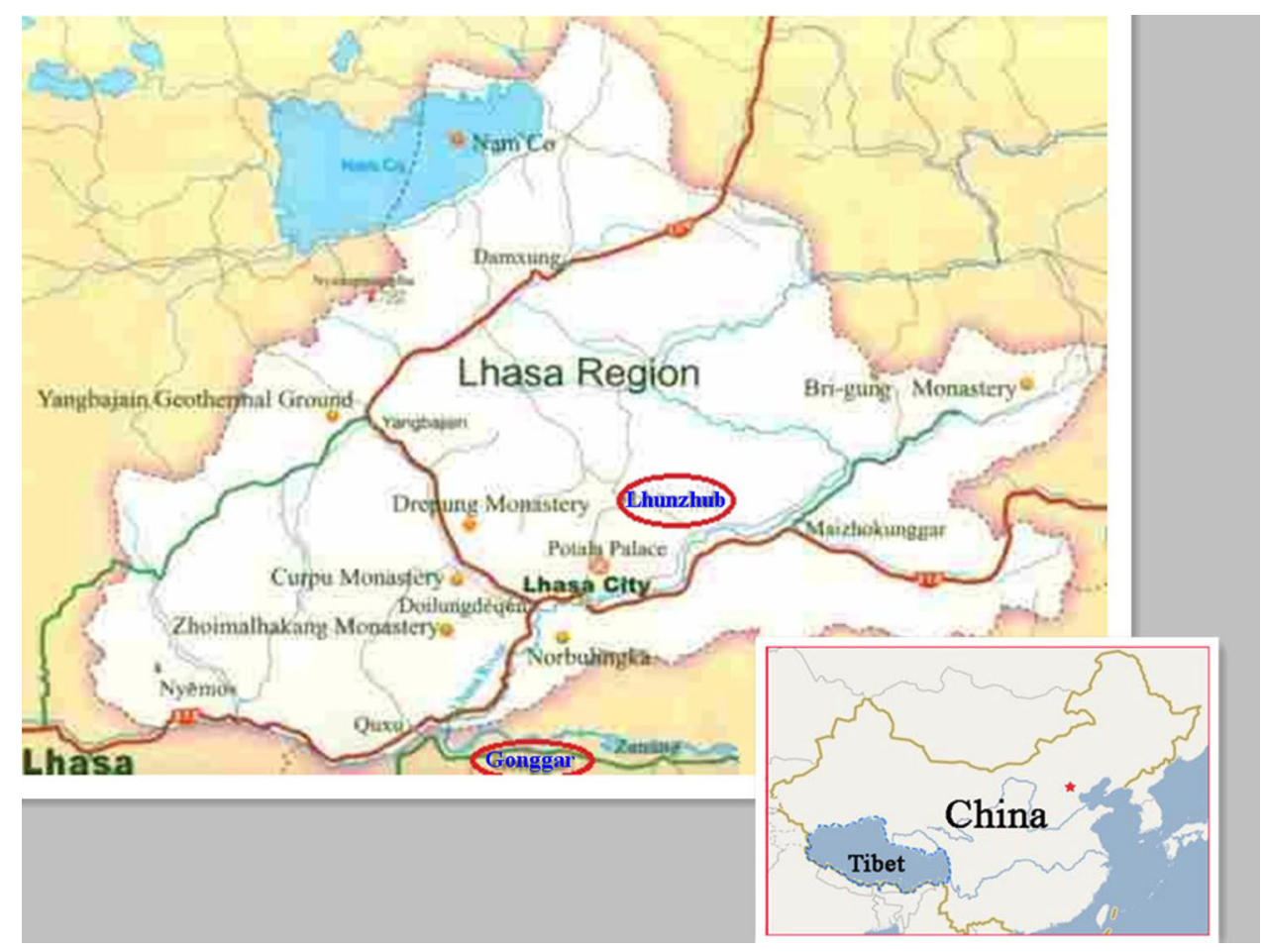

Table 1 Comparison between the measured value and certified value in GBW08571

\begin{tabular}{llllllllll}
\hline Elements & $\mathrm{Cr}$ & $\mathrm{As}$ & $\mathrm{Cd}$ & $\mathrm{Pb}$ & $\mathrm{Cu}$ & $\mathrm{Ba}$ & $\mathrm{Co}$ & $\mathrm{Mn}$ & $\mathrm{V}$ \\
\hline Measured value & $0.80(0.05)$ & $6.7(0.1)^{\mathrm{a}}$ & $3.6(0.02)$ & $1.61(0.02)$ & $7.2(0.1)$ & $0.99(0.08)$ & $0.87(0.02)$ & $9.0(0.2)$ & $0.48(0.03)$ \\
Certified value & $0.57(0.04)$ & $6.1(0.6)$ & $4.5(0.3)$ & $1.96(0.05)$ & $7.7(0.5)$ & ${ }^{\mathrm{b}}$ & $0.94(0.03)$ & $10.2(0.9)$ & - \\
\hline
\end{tabular}

${ }^{a}$ Average (Standard deviation), $\mu \mathrm{g} / \mathrm{g}$

b No certified values

Quality assurance and quality control

A mussel (GBW08571) standard reference material (SRM) was applied for validation of the analytical procedure. The results showed a good agreement with the certificate values, which suggested that the analytical procedures were reliable (Table 1). All analyses were performed 3 times using the external calibration method.

Tolerable daily intake of $\mathrm{As}, \mathrm{Cd}$ and $\mathrm{Pb}$ and estimated daily intake of heavy metals through fish consumption

Tolerable daily intakes (TDIs) of toxic metals such as As, $\mathrm{Cd}$ and $\mathrm{Pb}$ adopted in this study were according to the FAO/WHO's PTWIs (UNEP 1992; WHO 1993). The PTWIs showed safe exposure levels, which were used to estimate the amount of contaminants ingested over a lifetime without risk.

The daily intake of metals depends on both the metal concentration and the food consumption. Besides, the body weight of the human is also related to the tolerance of pollutants. The dose calculations were carried out using standard assumptions from an integrated United States EPA risk analysis. In this study, we assumed that ingested dose is equal to the absorbed pollutant dose (USEPA 1989), cooking has no effect on the pollutants (Cooper et al. 1991), and the average adult body weights of the Chinese is $55.9 \mathrm{~kg}$ (Ge 1992).

The estimated daily intake (EDI) is a concept introduced to take into account these factors. The EDI was calculated as follows:

$\mathrm{EDI}=\frac{\mathrm{C} \times \text { Cons }}{\mathrm{Bw}}$

where $\mathrm{C}$ is the concentration of heavy metals in fish, Con is the average daily consumption of fish in the local area, and $\mathrm{Bw}$ represents the body weight. Jiang et al. (2005) estimated that people who lived in coastal area of China would eat $105 \mathrm{~g}$ fish and crayfish per day. Since the consumption of fish in Tibet is less than that of coastal areas, so the 
Table 2 Mean heavy metal concentrations $( \pm$ S.E.) $(\mu \mathrm{g} / \mathrm{kg}$, wet weight) in muscle, gill, heart and liver tissues of big-head carps $(\mathrm{S} 1-\mathrm{S} 16)$ from Lhunzhun fishery

\begin{tabular}{lllll}
\hline Element & Muscle & Gill & Heart & Liver \\
\hline $\mathrm{Cr}(\mu \mathrm{g} / \mathrm{kg})$ & $17.93 \pm 5.64 \mathrm{a}$ & $41.26 \pm 8.00 \mathrm{~b}$ & $11.67 \pm 2.68 \mathrm{a}$ & $12.42 \pm 3.99 \mathrm{a}$ \\
$\mathrm{As}(\mu \mathrm{g} / \mathrm{kg})$ & $34.00 \pm 3.87$ & $35.17 \pm 8.18$ & $39.23 \pm 7.19$ & $65.88 \pm 20.40$ \\
$\mathrm{Cd}(\mu \mathrm{g} / \mathrm{kg})$ & n.d. & $5.56 \pm 0.33 \mathrm{a}$ & $7.52 \pm 0.82 \mathrm{a}$ & $12.22 \pm 1.59 \mathrm{~b}$ \\
$\mathrm{~Pb}(\mu \mathrm{g} / \mathrm{kg})$ & $22.70 \pm 1.80 \mathrm{a}$ & $93.75 \pm 10.33 \mathrm{~b}$ & $24.26 \pm 2.76 \mathrm{a}$ & $65.03 \pm 13.20 \mathrm{c}$ \\
$\mathrm{Cu}(\mu \mathrm{g} / \mathrm{kg})$ & $257.76 \pm 79.14 \mathrm{a}$ & $455.82 \pm 25.11 \mathrm{~b}$ & $2260.4 \pm 81.42 \mathrm{c}$ & $749.15 \pm 50.12 \mathrm{~d}$ \\
$\mathrm{Ba}(\mu \mathrm{g} / \mathrm{kg})$ & $474.00 \pm 39.97 \mathrm{a}$ & $13957.4 \pm 2283.7 \mathrm{~b}$ & $19.19 \pm 8.02 \mathrm{a}$ & $14.24 \pm 9.03 \mathrm{a}$ \\
$\mathrm{Co}(\mu \mathrm{g} / \mathrm{kg})$ & $8.35 \pm 0.62 \mathrm{a}$ & $69.81 \pm 5.69 \mathrm{~b}$ & $39.62 \pm 5.27 \mathrm{c}$ & $83.05 \pm 12.57 \mathrm{~b}$ \\
$\mathrm{Mn}(\mu \mathrm{g} / \mathrm{kg})$ & $778.97 \pm 107.67 \mathrm{a}$ & $109818.6 \pm 11487.8 \mathrm{~b}$ & $484.63 \pm 24.36 \mathrm{a}$ & $329.27 \pm 60.58 \mathrm{a}$ \\
$\mathrm{V}(\mu \mathrm{g} / \mathrm{kg})$ & $13.81 \pm 2.92 \mathrm{a}$ & $167.83 \pm 38.11 \mathrm{~b}$ & $27.51 \pm 4.82 \mathrm{a}$ & $107.07 \pm 18.03 \mathrm{~b}$ \\
\hline
\end{tabular}

n.d.: below detection limit; Limits of detection of measurements are $0.01 \mu \mathrm{g} / \mathrm{kg}$ d.w. for Cd. Values within the same row with different letters are significantly different $(p<0.05)$

average daily consumption was set to $80 \mathrm{~g}$. The average adult body weights assumed to be $55.9 \mathrm{~kg}$.

Statistical analysis

All the results were expressed on a wet weight basis. ANOVA was applied to detect significant differences. The correlation analysis was conducted by Pearson correlation coefficient, and 0.05 is set as the significant level. All statistical analyses were performed with SPSS 16.0.

\section{Results and discussion}

Comparison of heavy metals in different tissues of fishes

Nine heavy metals in different tissues of fish samples collected from two aquaculture fish farms were quantified, the results were shown in Tables 2, 3, 4, and 5. Among the four fish species, we found that $\mathrm{Cr}$ levels were higher in the gills than those in other tissues. In big-head carps, carps and grass carps, the concentrations of $\mathrm{Ba}, \mathrm{Co}, \mathrm{Mn}$ and $\mathrm{V}$ in gill samples were highest among all the tissues. And there is a little different in tilapias, the concentrations of Co and $\mathrm{V}$ in the heart were higher than in other tissues. The results suggested that heart can accumulate large amounts of $\mathrm{Cu}$, and the gill can accumulate a lot of $\mathrm{Ba}, \mathrm{Co}, \mathrm{Mn}$ and $\mathrm{V}$. This result partly are similar to the opinion reported by Skoric et al. (2012), they found that gills had the maximum concentrations of $\mathrm{Mn}$ and $\mathrm{Ba}$ in studied species. The concentration of As in different tissues were not significantly different in big-head carps and grass carps $(p>0.05)$, while in carps and tilapias, the contents of As are similar among the four tissues. $\mathrm{Cd}$ and $\mathrm{Pb}$ were concerned highly due to their toxicity, but in our study, Cd levels in all muscle samples were under detection limit, and $\mathrm{Pb}$ levels were also lowest in muscle among these studied tissues. Our results implied the muscle generally had lower accumulation capacity for heavy metal than the other tissues, which is in accordance with findings in sterlet (Acipenser ruthenus) and Pontic shad (Alosa immaculate) (Poleksic et al. 2010; Visnjic-Jeftic et al. 2010; Jaric et al. 2011).

Comparison with national standards and other studies

The detailed information of heavy metals in fish muscles and related water samples were listed in Tables 6 and 7. By comparing Tables 2, 3, 4, 5 and 6, 7, as concentrations were much higher in fish samples than water samples, and other heavy metals were comparable between water and fish samples, which might indicate the accumulation of As in fish. The concentrations of several toxic elements, such as $\mathrm{Cr}, \mathrm{Cd}$ and $\mathrm{Pb}$, in the muscle of the four fish species from Lhasa are apparently lower than those from other areas (Xie et al. 2010; Türkmen et al. 2005; Skoric et al. 2012). The maximum concentration of As in the muscle of tilapia reached $420.32 \mu \mathrm{g} / \mathrm{kg}$, which was approximately ten times higher than in the other three fishes in this study. The copper contents in fish muscle this area were comparable with that in other areas (Xie et al. 2010; Türkmen et al. 2005; Skoric et al. 2012). According to the national standards for maximum allowable levels of contaminants in foods (GB 2762-2005) and tolerance limit of copper in foods (GB 15199-94), the maximum allowable levels of contaminants (MLs) of $\mathrm{Cr}, \mathrm{As}, \mathrm{Cd}, \mathrm{Pb}$ and $\mathrm{Cu}$ are 2.0, 0.1, $0.1,0.5$ and $50 \mu \mathrm{g} / \mathrm{g}$ in fish, respectively. The concentrations of $\mathrm{Cr}, \mathrm{Cd}, \mathrm{Pb}$ and $\mathrm{Cu}$ in the muscle of the four fish species did not exceed the MLs, arsenic level in the muscle of the tilapia ranged from 211.30 to $420.32 \mu \mathrm{g} / \mathrm{kg}$, which exceeded the MLs $(100 \mu \mathrm{g} / \mathrm{kg})$ by $2.1-4.2$-folds. These results indicated that fishes from the aquaculture fish farm around Lhasa were not serious polluted by heacy metals expect As in tilapia. The tilapia was most seriously 
Table 3 Mean heavy metal concentrations ( \pm S.E.) ( $\mu \mathrm{g} / \mathrm{kg}$, wet weight) in muscle, gill, heart and liver tissues of carps (S7-S11) from Gonggar fishery

\begin{tabular}{lllll}
\hline Element & Muscle & Gill & Heart & Liver \\
\hline $\mathrm{Cr}(\mu \mathrm{g} / \mathrm{kg})$ & $2.39 \pm 1.13 \mathrm{a}$ & $82.76 \pm 25.82 \mathrm{~b}$ & n.d. & $24.91 \pm 10.01 \mathrm{a}$ \\
$\mathrm{As}(\mu \mathrm{g} / \mathrm{kg})$ & $13.69 \pm 3.91 \mathrm{a}$ & $50.16 \pm 11.30 \mathrm{~b}$ & $35.45 \pm 16.22 \mathrm{ab}$ & $50.35 \pm 4.12 \mathrm{~b}$ \\
$\mathrm{Cd}(\mu \mathrm{g} / \mathrm{kg})$ & $4.24 \pm 0.60 \mathrm{a}$ & $10.34 \pm 0.31 \mathrm{a}$ & $23.67 \pm 2.61 \mathrm{a}$ & $86.18 \pm 22.44 \mathrm{~b}$ \\
$\mathrm{~Pb}(\mu \mathrm{g} / \mathrm{kg})$ & $43.56 \pm 5.41 \mathrm{a}$ & $296.74 \pm 41.55 \mathrm{ab}$ & $44.03 \pm 8.04 \mathrm{a}$ & $367.47 \pm 171.59 \mathrm{~b}$ \\
$\mathrm{Cu}(\mu \mathrm{g} / \mathrm{kg})$ & $162.73 \pm 18.14 \mathrm{a}$ & $639.67 \pm 53.95 \mathrm{~b}$ & $3408.2 \pm 144.69 \mathrm{c}$ & $763.83 \pm 85.31 \mathrm{~b}$ \\
$\mathrm{Ba}(\mu \mathrm{g} / \mathrm{kg})$ & $69.68 \pm 11.01 \mathrm{a}$ & $5761.7 \pm 1300.0 \mathrm{~b}$ & $11.30 \pm 5.09 \mathrm{a}$ & $39.75 \pm 18.13 \mathrm{a}$ \\
$\mathrm{Co}(\mu \mathrm{g} / \mathrm{kg})$ & $3.84 \pm 0.62 \mathrm{a}$ & $63.79 \pm 11.64 \mathrm{~b}$ & $12.17 \pm 1.96 \mathrm{a}$ & $21.75 \pm 6.17 \mathrm{a}$ \\
$\mathrm{Mn}(\mu \mathrm{g} / \mathrm{kg})$ & $238.05 \pm 22.39 \mathrm{a}$ & $72643.6 \pm 9134.3 \mathrm{~b}$ & $597.50 \pm 102.13 \mathrm{a}$ & $816.83 \pm 175.52 \mathrm{a}$ \\
$\mathrm{V}(\mu \mathrm{g} / \mathrm{kg})$ & $6.71 \pm 0.42 \mathrm{a}$ & $83.43 \pm 19.50 \mathrm{~b}$ & $9.62 \pm 2.90 \mathrm{a}$ & $55.44 \pm 15.58 \mathrm{~b}$ \\
\hline
\end{tabular}

n.d.: below detection limit; Limits of detection of measurements are $0.1 \mu \mathrm{g} / \mathrm{kg}$ d.w. for Cr. Values within the same row with different letters are significantly different $(p<0.05)$

Table 4 Mean heavy metal concentrations $( \pm$ S.E. $)(\mu \mathrm{g} / \mathrm{kg}$, wet weight) in muscle, gill, heart and liver tissues of grass carps (S12-S16) from Gonggar fishery with different letters are significantly different $(p<0.05)$

\begin{tabular}{lllll}
\hline Element & Muscle & Gill & Heart & Liver \\
\hline $\mathrm{Cr}(\mu \mathrm{g} / \mathrm{kg})$ & $5.04 \pm 2.17 \mathrm{a}$ & $55.45 \pm 8.69 \mathrm{~b}$ & $13.91 \pm 6.44 \mathrm{a}$ & $18.41 \pm 7.33 \mathrm{a}$ \\
$\mathrm{As}(\mu \mathrm{g} / \mathrm{kg})$ & $32.94 \pm 6.37$ & $39.16 \pm 1.57$ & $40.29 \pm 5.06$ & $53.17 \pm 20.12$ \\
$\mathrm{Cd}(\mu \mathrm{g} / \mathrm{kg})$ & $3.98 \pm 0.28 \mathrm{a}$ & $9.44 \pm 0.75 \mathrm{ab}$ & $28.09 \pm 2.81 \mathrm{~b}$ & $54.97 \pm 13.98 \mathrm{c}$ \\
$\mathrm{Pb}(\mu \mathrm{g} / \mathrm{kg})$ & $23.46 \pm 3.26 \mathrm{a}$ & $114.65 \pm 10.21 \mathrm{~b}$ & $91.46 \pm 10.23 \mathrm{~b}$ & $168.32 \pm 31.08 \mathrm{c}$ \\
$\mathrm{Cu}(\mu \mathrm{g} / \mathrm{kg})$ & $135.22 \pm 30.99 \mathrm{a}$ & $687.96 \pm 46.24 \mathrm{~b}$ & $3271.9 \pm 200.90 \mathrm{c}$ & $600.26 \pm 75.94 \mathrm{~b}$ \\
$\mathrm{Ba}(\mu \mathrm{g} / \mathrm{kg})$ & $63.50 \pm 17.23 \mathrm{a}$ & $10090.7 \pm 1567.1 \mathrm{~b}$ & $227.25 \pm 155.18 \mathrm{a}$ & $7.11 \pm 3.22 \mathrm{a}$ \\
$\mathrm{Co}(\mu \mathrm{g} / \mathrm{kg})$ & $7.66 \pm 1.56 \mathrm{a}$ & $124.81 \pm 7.84 \mathrm{~b}$ & $49.86 \pm 5.82 \mathrm{c}$ & $46.98 \pm 14.15 \mathrm{c}$ \\
$\mathrm{Mn}(\mu \mathrm{g} / \mathrm{kg})$ & $154.31 \pm 16.98 \mathrm{a}$ & $4051.5 \pm 291.19 \mathrm{~b}$ & $664.51 \pm 208.21 \mathrm{a}$ & $251.54 \pm 20.43 \mathrm{a}$ \\
$\mathrm{V}(\mu \mathrm{g} / \mathrm{kg})$ & $8.30 \pm 0.57 \mathrm{a}$ & $47.10 \pm 3.75 \mathrm{~b}$ & $19.10 \pm 4.55 \mathrm{a}$ & $105.59 \pm 23.87 \mathrm{c}$ \\
\hline
\end{tabular}

Table 5 Mean heavy metal concentrations $( \pm$ S.E.) ( $\mu \mathrm{g} / \mathrm{kg}$, wet weight) in muscle, gill, heart and liver tissues of tilapias (S17-S21) from Gonggar fishery

\begin{tabular}{lllll}
\hline Element & Muscle & Gill & Heart & Liver \\
\hline $\mathrm{Cr}(\mu \mathrm{g} / \mathrm{kg})$ & $2.36 \pm 0.72 \mathrm{a}$ & $107.39 \pm 31.46 \mathrm{~b}$ & n.d. & $29.18 \pm 8.68 \mathrm{a}$ \\
$\mathrm{As}(\mu \mathrm{g} / \mathrm{kg})$ & $286.51 \pm 36.52 \mathrm{a}$ & $218.65 \pm 54.68 \mathrm{a}$ & $412.50 \pm 82.50 \mathrm{ab}$ & $607.07 \pm 152.52 \mathrm{~b}$ \\
$\mathrm{Cd}(\mu \mathrm{g} / \mathrm{kg})$ & $3.68 \pm 0.32 \mathrm{a}$ & $17.82 \pm 1.65 \mathrm{ab}$ & $70.41 \pm 22.82 \mathrm{~b}$ & $62.42 \pm 30.25 \mathrm{~b}$ \\
$\mathrm{~Pb}(\mu \mathrm{g} / \mathrm{kg})$ & $21.41 \pm 5.61 \mathrm{a}$ & $204.76 \pm 32.22 \mathrm{~b}$ & $131.96 \pm 23.80 \mathrm{ab}$ & $210.91 \pm 69.07 \mathrm{~b}$ \\
$\mathrm{Cu}(\mu \mathrm{g} / \mathrm{kg})$ & $149.17 \pm 12.10 \mathrm{a}$ & $840.07 \pm 139.19 \mathrm{a}$ & $3799.37 \pm 543.00 \mathrm{~b}$ & $823.97 \pm 256.89 \mathrm{a}$ \\
$\mathrm{Ba}(\mu \mathrm{g} / \mathrm{kg})$ & $13.87 \pm 9.49 \mathrm{a}$ & $764.80 \pm 98.71 \mathrm{~b}$ & $37.76 \pm 7.88 \mathrm{a}$ & $62.22 \pm 13.12 \mathrm{a}$ \\
$\mathrm{Co}(\mu \mathrm{g} / \mathrm{kg})$ & $4.93 \pm 0.77 \mathrm{a}$ & $37.77 \pm 7.18 \mathrm{a}$ & $546.03 \pm 118.96 \mathrm{~b}$ & $59.30 \pm 6.39 \mathrm{a}$ \\
$\mathrm{Mn}(\mu \mathrm{g} / \mathrm{kg})$ & $127.71 \pm 17.80 \mathrm{a}$ & $4567.31 \pm 908.66 \mathrm{~b}$ & $735.91 \pm 170.92 \mathrm{a}$ & $1520.75 \pm 251.80 \mathrm{a}$ \\
$\mathrm{V}(\mu \mathrm{g} / \mathrm{kg})$ & $6.16 \pm 0.11 \mathrm{a}$ & $69.22 \pm 24.89 \mathrm{~b}$ & $143.36 \pm 31.61 \mathrm{c}$ & $29.99 \pm 4.44 \mathrm{ab}$ \\
\hline
\end{tabular}

n.d.: below detection limit; Limits of detection of measurements are $0.1 \mu \mathrm{g} / \mathrm{kg}$ d.w. for Cr. Values within the same row with different letters are significantly different $(p<0.05)$

polluted by As, the reason may be that arsenic could be easily accumulated in the tilapia.

Human exposure to metals through fish

Local inhabitants might experience heavy metal exposure by consuming fish in this region. The TDIs for As, Cd and
$\mathrm{Pb}$ were set at 50.0, 1.0 and $3.6 \mu \mathrm{g} / \mathrm{day} \mathrm{kg}$ bw according to the Joint FAO/WHO Expert Committee on Food Additives (JECFA) (UNEP 1992; WHO 1993), respectively. The EDI that was calculated from Eq. (1), which is based on fish consumption amount and heavy metal levels of the fish samples. The estimated maximum daily intake (MaxI) for $\mathrm{As}, \mathrm{Cd}$ and $\mathrm{Pb}$ are shown in Fig. 2. However, the maximum 
Table 6 Heavy metal concentrations $( \pm$ S.E. $)(\mu \mathrm{g} / \mathrm{L}$, wet weight) in water samples from different fish ponds

\begin{tabular}{lllllll}
\hline & $\mathrm{Cr}$ & $\mathrm{As}$ & $\mathrm{Pb}$ & $\mathrm{Cu}$ & $\mathrm{Co}$ & $\mathrm{Ni}$ \\
\hline $\begin{array}{l}\text { Big-head carp } \\
\text { pond }\end{array}$ & $8.83 \pm 0.79$ & $2.44 \pm 0.11$ & $3.40 \pm 0.87$ & $9.36 \pm 0.75$ & $1.26 \pm 0.11$ & $3.26 \pm 0.37$ \\
Carp pond & $1.88 \pm 0.89$ & $21.04 \pm 1.79$ & $3.21 \pm 0.56$ & $3.78 \pm 1.45$ & $1.59 \pm 0.64$ & $5.45 \pm 1.26$ \\
Grass carp pond & $1.64 \pm 0.29$ & $29.10 \pm 4.61$ & $3.94 \pm 0.29$ & $6.51 \pm 0.89$ & $2.08 \pm 0.37$ & $8.32 \pm 1.09$ \\
Tilapia pond & $1.98 \pm 0.37$ & $35.41 \pm 1.22$ & $2.45 \pm 0.17$ & $2.68 \pm 0.38$ & $1.54 \pm 0.02$ & $5.55 \pm 0.42$ \\
\hline
\end{tabular}

Table 7 Comparison of heavy metal concentrations in fish muscle samples with data available from previous studies

\begin{tabular}{llllll}
\hline Species or Area & $\mathrm{Cr}$ & $\mathrm{As}$ & $\mathrm{Cd}$ & $\mathrm{Pb}$ & $\mathrm{Cu}$ \\
\hline Big-head carp & $2.66-38.46$ & $24.75-48.41$ & n.d. & $19.07-30.60$ & $120.76-636.80$ \\
Carp & $1.06-3.72$ & $3.89-22.57$ & $2.48-5.56$ & $31.50-56.04$ & $121.08-204.19$ \\
Grass carp & $2.47-9.36$ & $12.91-49.49$ & $3.30-4.68$ & $14.04-27.98$ & $48.45-241.62$ \\
Tilapia & $0.93-4.03$ & $211.30-420.32$ & $2.58-4.34$ & $5.93-40.62$ & $105.40-173.16$ \\
Pearl River $^{\mathrm{a}}$ & n.d.-5.36 & $0.17-1.46$ & n.d.-33.2 & $0.05-1.94$ & $1.17-6.72$ \\
Iskenderun Bay $^{\text {b }}$ & $1.309-2.719$ & & $0.831-1.341$ & $1.808-3.474$ & $1.239-2.201$ \\
Tisza River & & 2.34 & & n.d. & 3.08 \\
MLs & 2,000 & 100 & 100 & 500 & 50,000 \\
\hline
\end{tabular}

MLs represent the maximum levels of contaminants in the national standards expressed as $\mu \mathrm{g} / \mathrm{kg}$ dry wt

a Xie et al. (2010) values represent the ranges expressed as $\mathrm{mg} / \mathrm{kg}$ dry wt

b Türkmen et al. (2005) values represent the ranges expressed as $\mathrm{mg} / \mathrm{kg}$ wet wt

${ }^{c}$ Skoric et al. (2012) values represent the ranges expressed as $\mathrm{mg} / \mathrm{kg}$ dry wt

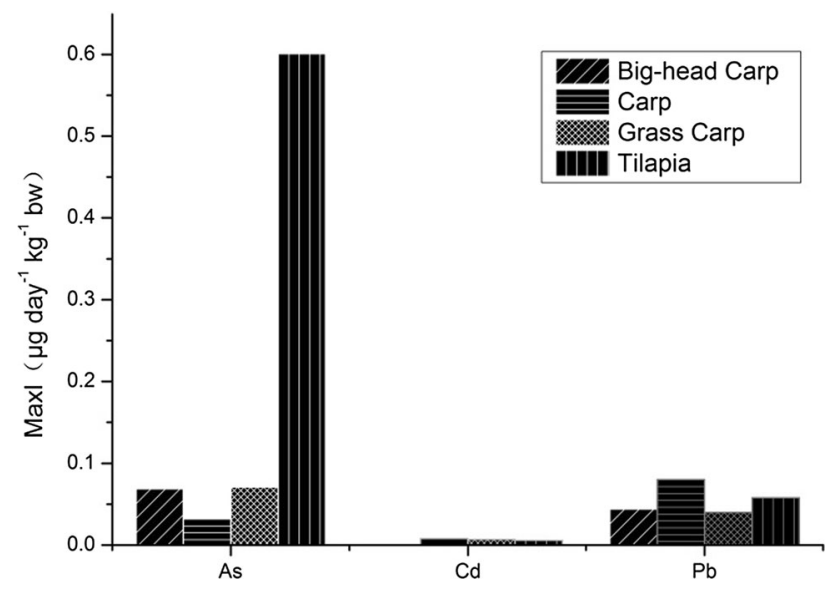

Fig. 2 Mean estimated maximum daily intake by a $55.9 \mathrm{~kg}$ body weight person in Lhasa

values of MaxI for $\mathrm{As}, \mathrm{Cd}$ and $\mathrm{Pb}$ were $0.601,0.008$ and $0.080 \mu \mathrm{g} / \mathrm{day} \mathrm{kg}$ bw, respectively, they were much lower than the TDI. This result indicated that people consumed local fish might not have adverse effect to their health. However, the EDI here was only evaluated in fishes, which accounts for only a fraction of the contamination through daily dietary consumption. As a result, daily intake of fish grown in this area might not cause detrimental health hazards to the consumers, but we should make further research to ensure the local inhabitants' health.

\section{Conclusion}

From this study, we obtained a better knowledge of heavy metals levels in fish from aquaculture farm in Tibet and the potential risk on human health. Based on our study, the aquaculture fish farms around Lhasa were not serious polluted by heavy metals. Generally, toxic metals (As, Cd and $\mathrm{Pb}$ ) contents in the liver were higher than those in other tissues, heavy metal levels in muscle were the lowest among the different tissues. Besides, we found that $\mathrm{Cr}$, Ba, $\mathrm{Co}, \mathrm{Mn}$ and $\mathrm{V}$ were prone to accumulate in the gill, and $\mathrm{Cu}$ was highly accumulated in the hearts of fish. Compared to the national standards, As content in the tilapia samples was $\sim 2-4$ times higher than the MLs by the national standard, other metals were all lower than the MLs. By estimating the daily intake of $\mathrm{As}, \mathrm{Cd}$ and $\mathrm{Pb}$ through fish consumption by the local inhabitants, we concluded that daily intake of these metals in this area did not exceed the TDI recommended by FAO. However, the consumption of fish accompanying with other local foods such as meat, milk and crop will probably contribute to elevated levels of both metals. But relevant data are still limited in this area, so further studies need to be conducted. 
Acknowledgments We would like to thank Mr. Wang and $\mathrm{Mr}$. Shuai, the owners of Lhunzhun fishery and Gonggar fishery, respectively, for their constant assistance and contribution in sample collection during this project. This study was supported by National Natural Science Foundation of China (No. 31072217), National Major Project of Science \& Technology Ministry of China (No. 2012ZX07501-003, 2013ZX07101-014), Foundation of the State University of innovative pilot project (No. 091069404), Open Research Fund of State Key Laboratory of Environmental Chemistry and Ecotoxicology (KF2009-19, 20) and Chinese Academy of Sciences and the Tibet Autonomous Region People's government cooperation project (XBCD-2011-017).

Conflict of interest The authors declare that they have no conflict of interests with this research.

\section{References}

Almeida JA, Diniz YS, Marques SFG, Faine IA, Ribas BO, Burneiko RC, Novelli EIB (2002) The use of oxidative stress responses as biomarkers in Nile Tilapia (Oreochromis niloticus) exposed to in vivo cadmium contamination. Environ Int 27:673-679

Baars A, Theelen R, Janssen P, Hesse J, van Apeldoorn M, Meijerink M, Verdam L, Zeilmaker M (2001) Re-evaluation of human toxicological maximum permissible risk levels. RIVM Rep 711701:025

Castro-Gonzalez IM (2002) Acidos grasos omega-3: beneficios y Fuentes. Interciencia 27:128-136

Clarkson WT (2002) The three modern faces of mercury. Environ Health Perspect 110:11-23

Cooper CB, Doyle ME, Kipp K (1991) Risk of consumption of contaminated sea-food, the Quincy Bay Case Study. Environ Health Perspect 90:133-140

Devlin EW (2006) Acute toxicity, uptake and histopathology of aqueous methyl mercury to fathead minnow embryos. Ecotoxicology 15(1):97-110. doi:10.1007/s10646-005-0051-3

Dominogo JL, Bocio A, Flaco G, Llobet JM (2007) Benefits and risk of fish consumption. Part I. A quantitative analysis of the intake of omega- 3 fatty acids and chemical contaminants. Toxicology 230:219-226

Ge KY (1992) The Status of Nutrient and Meal of Chinese in the 1990s. Hygiene Press, Beijing, pp 415-434

Heier LS, Lien IB, Strømseng AE, Ljønes M, Rosseland BO, Tollefsen KE, Salbu B (2009) Speciation of lead, copper, zinc and antimony in water draining a shooting range-time dependant metal accumulation and biomarker responses in brown trout (Salmo trutta L.). Sci Total Environ 407(13):4047-4055

Huang X, Sillanpää M, Gjessing ET, Peräniemi S, Vogt RD (2010) Environmental impact of mining activities on the surface water quality in Tibet: Gyama valley. Sci Total Environ 408(19):4177-4184

Jaric I, Visnjic-Jeftic Z, Cvijanovic G, Gacic Z, Jovanovic Lj, Skoric S, Lenhardt M (2011) Determination of differential heavy metal and trace element accumulation in liver, gills, intestine and muscle of sterlet (Acipenser ruthenus) from the Danube River in Serbia by ICP-OES. Microchem J 98:77-81

Jiang QT, Lee TKM, Chen K, Wong HL, Zheng JS, Giesy JP, Lo KKW, Yamashitad N, Lam PKS (2005) Human health risk assessment of organochlorines associated with fish consumption in a coastal city in China. Environ Pollut 136:155-165

Jones I, Kille P, Sweeney G (2001) Cadmiun delays growth hormone expression during rainbow trout development. J Fish Biol 59:1015-1022
Kris-Etherton PM, Harris WS, Appel LJ (2002) Fish consumption, fish oil. Omega-3 fatty acids, and cardiovascular disease. Circulation 106:2747-2757

Macken A, Giltrap M, Ryall K, Foley B, McGovern E, McHugh B, Davoren M (2009) A test battery approach to the ecotoxicological evaluation of cadmium and copper employing a battery of marine bioassays. Ecotoxicology 18(4):470-480. doi:10.1007/ s10646-009-0305-6

Megeer JC, Szebedinszky C, McDonald DG, Wood CM (2000) Effect of chronic sublethal exposure to waterborne $\mathrm{Cu}, \mathrm{Cd}$, or $\mathrm{Zn}$ in rainbow trout 1: iono-regulatory disturbance and metabolic costs. Aquat Toxicol 50(3):231-243

Ozmen M, Gungordu A, Kucukbay FZ, Guler RE (2006) Monitoring the effects of water pollution on Cyprinus carpio in Karakaya Dam Lake, Turkey. Ecotoxicology 15(2):157-169. doi:10.1007/ s10646-005-0045-1

Poleksic V, Lenhardt M, Jaric I, Djordjevic D, Gacic Z, Cvijanovic G, Raskovic B (2010) Liver, gills and skin histopathology and heavy metal content of the Danube Sterlet (Acipenser ruthenus LINNAEUS, 1758). Environ Toxicol Chem 29:515-521

Ramirez-Perez T, Sarma SSS, Nandini S (2004) Effects of mercury on the life table demography of the rotifer Brachionus calyciflorus pallas (rotifera). Ecotoxicology 13(6):535-544. doi:10.1023/b: ectx.0000037190.09248.62

Sawasdee B, Kohler HR (2010) Metal sensitivity of the embryonic development of the ramshorn snail Marisa cornuarietis (Prosobranchia). Ecotoxicology 19(8):1487-1495. doi:10.1007/ s10646-010-0534-8

Silva KTU, Pathiratne A (2008) In vitro and in vivo effects of cadmium on cholinesterases in Nile tilapia fingerlings: implications for biomonitoring aquatic pollution. Ecotoxicology 17(8):725-731. doi:10.1007/s10646-008-0221-1

Skoric S, Visnjić-Jeftic Z, Jaric I, Djikanovic V, Mickovic B, Nikcevic M, Lenhardt M (2012) Accumulation of 20 elements in great cormorant (Phalacrocorax carbo) and its main prey, common carp (Cyprinus carpio) and Prussian carp (Carassius gibelio). Ecotoxicol Environ Saf 80:244-251

Türkmen A, Türkmen M, Tepe Y, Akyurt I (2005) Heavy metals in three commercially valuable fish species from Iskenderun Bay, Northern East Mediterranean Sea. Turk Food Chem 91:167-172

UNEP/FAO/WHO (1992) Assessment of dietary intake of chemical contaminants. United Nations Environmental Program, Nairobi

USEPA (1989) Risk assessment guidance for superfund. In: Human Health Evaluation Manual Part A, Interim Final, vol. I. United States Environmental Protection Agency, Washington, DC. 1989 EPA/540/1-89/002

Visnjic-Jeftic Z, Jaric I, Jovanovic Lj, Skoric S, Smederevac-Lalic M, Nikcevic M, Lenhardt M (2010) Heavy metal and trace element accumulation in muscle, liver and gills of the Pontic shad (Alosa immaculata Bennet 1835) from the Danube River (Serbia). Microchem J 95:341-344

WHO, World Health Organization (1993) Evaluation of certain food additives and contaminants (41st report of the joint FAO/WHO expert committee on food additives). WHO Tech. Reports Series No. 837

Xie WP, Chen KC, Zhu XP, Nie XP, Zhen GM, Pan DB, Wang SB (2010) Evaluation on heavy metal contents in water and fi shes collected from the waterway in the Pearl River Delta, South China. J Agro Environ Sci 29(10):1917-1923 (in Chinese)

Xu YJ, Liu XZ, Ma AJ (2004) Current research on toxicity effect and molecular mechanism of heavy metals on fish. Mar Sci 28(10):67-70 